\title{
STUDY REGARDING THE PARENTS' USE OF SELF - MEDICATION AMONG CHILDREN UNDER 12 YEARS OLD
}

\author{
CARMEN CRISTESCU ${ }^{1 \#}$, SIMONA NEGREȘ ${ }^{2 \#}$, MARIA SUCIU $^{1}$, ADRIAN VOICU $^{3}$, \\ VALENTINA BUDA $^{1}$, LIANA SUCIU $^{1}$, MARIA PROKS ${ }^{1}$, MIRELA VOICU ${ }^{1 *}$ \\ 1 "Victor Babes" University of Medicine and Pharmacy, Faculty of Pharmacy, Department of Pharmacology-Clinical Pharmacy, \\ Timişoara, Romania \\ 2 "Carol Davila” University of Medicine and Pharmacy, Faculty of Pharmacy, Department of Pharmacology-Clinical Pharmacy, \\ Bucharest, Romania \\ 3 "Victor Babes" University of Medicine and Pharmacy, Faculty of Medicine, Department of Functional Sciences, Timişoara, \\ Romania
}

*corresponding author: voicu.mirela@umft.ro

${ }^{\#}$ Authors with equal contribution

Manuscript received: April 2018

\begin{abstract}
The practice of self-medication in paediatrics is a phenomenon with increasing incidence, despite the fact that the FDA (Food and Drug Administration) published, in 2011, a number of recommendations and restrictions on the OTC (over the counter) medication administered in children under 12 years old. The objective of the study was to identify the prevalence of selfmedication carried out by parents in their under 12 years old children and to evaluate the associated determinants. We conducted a retrospective study (from 1 February to 30 April 2016) based on a questionnaire targeting parents with children under 12 years old, who attended three kindergartens and three primary schools, in Timisoara, Romania. There were returned 582 questionnaires, of which 564 could be analysed (96.91\%). Mothers between 30 and 39 years old with university studies have most frequently resorted to self-medication $(71.27 \%)$, by going to the family medicines kit (83.61\%). Fever, pain and cough were the most common symptoms for which parents used self-medication, the most frequently used drugs were: antipyretic analgesics (92.74\%), antitussives/expectorants (83.84\%), vitamins and nutritional supplements (49.14\%), nasal decongestants $(40.14 \%)$. Homeopathic remedies were quoted by $31.84 \%$ of parents. The main sources of information for the parents were the doctor, the pharmacist and the patient information leaflet of the drug. The study reveals an increased prevalence of self-medication in children under 12 years old $(81.02 \%)$, even with drugs outside the paediatric guidelines.
\end{abstract}

\section{Rezumat}

Practica automedicaţiei în pediatrie este un fenomen cu incidenţă crescândă, deşi în 2011 FDA a publicat o serie de recomandări şi restricţii privind medicaţia de tip OTC adresată copiilor sub 12 ani. Obiectivul studiului a fost determinarea prevalenţei automedicaţiei copiilor sub 12 ani de către părinţi şi evaluarea factorilor care îi sunt asociaţi. Am realizat un studiu retrospectiv pe baza unui chestionar adresat părinţilor ai căror copii sub 12 ani au frecventat între 1 februarie şi 30 aprilie 2016, grădiniţe şi şcoli din Timişoara, România. Au fost returnate 582 de chestionare, dintre care 564 au fost analizabile (96,91\%). Mamele, cu vârsta cuprinsă între 30 şi 39 de ani şi studii universitare au recurs cel mai frecvent la automedicaţia copilului $(71,27 \%)$, majoritatea apelând la medicaţia existentă acasă $(83,61 \%)$. Febra, durerea şi tusea au fost simptomele pentru care părinţii au recurs cel mai frecvent la automedicaţia copilului. Medicamentele cele mai frecvent administrate copiilor sub formă de automedicaţie au fost: analgezice antipiretice $(92,74 \%)$, antitusive/expectorante $(83,84 \%)$, vitamine şi suplimente nutritive (49,14\%), decongestionante nazale (40,14\%). Medicamentele homeopate au fost citate de $31,84 \%$ dintre părinţi. Principalele surse de informare ale părinţilor au fost medicul, farmacistul şi prospectul medicamentelor. Studiul relevă o prevalenţă crescută a automedicaţiei la copilul sub 12 ani $(81,02 \%)$, chiar cu medicamente în afara reglementărilor pediatrice în vigoare.

Keywords: self-medication, paediatrics, survey, risks

\section{Introduction}

According to the World Health Organization (WHO), rational use of drugs implies that patients use the right drugs according to the individual clinical context, in the right doses, on a well-determined period of time and at an affordable price [9].
WHO's recent appraisal shows that the worldwide consumption of drugs which do not require a medical prescription is a common practice of everyday life, in all patients' age groups, regardless of their age $[1,9,10]$. 
FARMACIA, 2018, Vol. 66, 5

The practice of self-medication by the adult population and the elderly is a phenomenon with increasing incidence and an aspect reflected by multiple studies $[8,14]$.

However, we do not have enough published data on the practice of self-medication in children under the age of 12, this under-investigated behaviour being likely to follow the same pattern as in adults and the elderly.

The phenomenon is highly important especially referring to the following aspects: (i) increased vulnerability of children to drugs (especially in infants and children under 3 years old) due to the significant pharmacokinetic and pharmacodynamic differences in the administered medication [4, 12]; (ii) increased incidence of drug errors and iatrogenic risk in children under 12 years old [16, 18, 20].

In order to limit the dosage and medication errors in patients under the age of 12 , it is very important that: a) parents be advised to use paediatric pharmaceutical forms during childhood, preferably by oral formulations (drinkable solutions, syrups, etc.); b) the medical and the pharmaceutical staff need to know the reasons why parents chose self-medication for their children. This study aimed primarily to assess the prevalence of self-medication in children under the age of 12 given by their parents in order to implement an informed and therapeutically educative program based on the "irresponsible" self-medication risks in the paediatric population.

Secondly, this study also aimed to: describe the reasons for which parents prefer to self-medicate their children's various pathological symptoms; know the medical problems treated by parents without asking for a medical advice; identify the most common used drugs in self-medication in children under the age of 12; highlight the parental knowledge about the efficacy and the potential toxicity of two mainly used drugs in paediatric pathology (paracetamol versus ibuprofen); assess the parents' knowledge on the risks of self-medication in children.

\section{Materials and Methods}

\section{The setting}

We conducted a transversal, descriptive study, between $1^{\text {st }}$ of February and $30^{\text {th }}$ April 2016 , on assessing the prevalence of self-medication practices in parents with children under the age of 12 , based on the data collected from a questionnaire. This questionnaire was addressed to parents whose children attended communities in Timisoara corresponding to their age. The study was approved by the Ethics Committee of "Victor Babeş" University of Medicine and Pharmacy, Timişoara, Romania.

The selection of children's communities was based on their location in relation to the area of the
Faculty of Pharmacy and the availability of parents to complete the questionnaire.

Inclusion criteria

All the parents/belongings of the children under 12 years old who accepted to respond to the questionnaire were included in this study.

The population studied

The study included 564 parents with children (under the age of 12) enrolled in 6 profile units in Timișoara, Romania (3 kindergartens and 3 primary-schools).

The modality of collecting the data

For this study, we used a 20-questions questionnaire in a varied format: multiple choice questions or a single response options and also open questions, such as "Can you list some of the risks of selfmedication in children?".

Each questionnaire contained a standard, concise introduction, specifying the anonymity of the given answers and the objectives of the study, to the parents. Through the questions included in the questionnaire we aimed to obtain 4 types of information needed to achieve the proposed objectives in the study: data on the child's health problems, data on administered drugs, data aimed to identify parents' opinions on the efficacy and potential toxicity of paracetamol versus ibuprofen and data about the parents' knowledge of self-medication risks in children.

To assess the degree of understanding the questions, the questionnaire was pretested on a sample of 10 parents. This phase of the testing allowed us to rephrase the questions that were considered too complex.

Subsequently, the questionnaires were distributed to all parents whose children under 12 have attended the selected educational institutions. They were able to answer the questionnaire's items at school or at home and to return it.

Statistical analyses

Internal data consistency was calculated using the Cronbach-alpha index. Its calculated value was $\alpha=0.778$ for a total of 45 items.

By verifying the collected data and by removing the "No, never" item (redundant) it resulted in an increase of the Cronbach-alpha index to the value of $\alpha=0.811$. The information's analysis obtained through the questionnaires was done using Microsoft ${ }^{\circledR}$ Excel 2016 for data centralization and R (free statistical software) for their processing.

To evaluate the influence of the most representative variables used in the study we used the method of generalized linear models for binomial distributions. The questionnaire was imported into $\mathrm{R}$ and the glm (general linearized model) package was used for processing the data.

For the initial model we used all the variables. After running it, it is noticed that not all the variables considered are statistically significant, and therefore do not significantly influence the automated decision. 
Akaike's information criterion (AIC) compares the quality of a set of statistical models to each other. The initial value obtained for Akaike Information Criterion (AIC) is $\mathrm{AIC}=359.23$. It is therefore necessary to simplify the model.

The investigators

The questionnaires were handed to the teaching staff (of the kindergartens and primary schools) who were in direct contact with the children's parents. Each responsible for the children's group was informed, by the clinical pharmacy residents participating in the survey, about the structure of the questionnaire (clarifying any unclear aspect) and the deadline of data collection.

\section{Results and Discussion}

582 questionnaires were returned from the selected communities, out of which 564 were able to be analysed (96.91\%). 18 questionnaires (3.09\%) were cancelled for various reasons: the age of children $>12$ years old, the lack of time or interest of the parents regarding the questionnaire completion.

\section{General data}

Distribution of questionnaires by location of data collection

The questionnaires included in this study, containing parents' opinions on the practice of self-medication in the paediatric population, came from 6 communities of children ( 3 kindergartens and 3 primary schools) who agreed to participate in this research. Most responses were obtained from parents whose children were in primary school (76.25\%).

Responders of the questionnaires

Most of the questionnaires were completed by the mothers $(79.07 \%), 16.31 \%$ by the fathers and $4.60 \%$ by other relatives (grandparents, other relatives) (Table I).

Studied population - general characteristics

Parents' group of age

The parents' average age who were enrolled in this study was $32 \pm 7$ years, with margins ranging from 19 to 47 years.

According to this criterion, we found that the highest percentage of respondent parents was in the age group of $30-39$ years $(58.33 \%)$. $78.41 \%$ of parents aged 30 - 39 years consider themselves sufficiently well informed about the drugs administered to their child to control their benign pathological complaints, at least at an initial stage.

Parents' level of education

In our study, parents with university studies were the first to self-medicate their child, representing according to this indicator the population with the highest representativeness $(67.73 \%)$. Only a small percentage of the parents who practiced self-medication in children said they completed secondary education studies $(1.41 \%)$ and the rest of $27.12 \%$ said they completed high school studies. $3.72 \%$ of the investigated parents did not respond to this question.

Descriptive data of the parents' population participating in the study

\begin{tabular}{|c|c|c|}
\hline Number of questionnaires & Number & Percentage (\%) \\
\hline Total & 600 & $100 \%$ \\
\hline Returned & 582 & $97.10 \%$ \\
\hline Excluded & 18 & $2.90 \%$ \\
\hline Reviewed & 564 & $96.90 \%$ \\
\hline Parents responding to the questionnaire & & \\
\hline Total & 564 & $79.07 \%$ \\
\hline Mother & 446 & $16.31 \%$ \\
\hline Father & 92 & $4.60 \%$ \\
\hline Other relatives & 26 & $2.83 \%$ \\
\hline Parents' group of age & & $26.06 \%$ \\
\hline$<20$ years & 16 & $58.33 \%$ \\
\hline 20 - 29 years & 147 & $12.76 \%$ \\
\hline $30-39$ years & 329 & \\
\hline$>40$ years & 72 & $67.73 \%$ \\
\hline Parents' level of education & & $27.12 \%$ \\
\hline University studies & 382 & $1.41 \%$ \\
\hline High school studies & 153 & $3.72 \%$ \\
\hline Gymnasium studies & 8 & \\
\hline Non-responders & 21 & \\
\hline
\end{tabular}

Prevalence of self-medication

By analysing the 564 questionnaires we found that 457 parents $(81.02 \%)$ stated that in the last 3 months they had resorted to self-medication for the treatment of various symptoms of their children.
107 parents (18.97\%) said they never practiced selfmedication for their children due to various reasons: fear of side effects (34.57\%), concerns about dosage errors $(27.10 \%)$, informative deficiencies $(15.88 \%)$, 
child suffering from a chronic medical condition $(7.47 \%)$, other reasons $(14.95 \%)$.

Data related to the self-medication's pharmacotherapy Parents' sources of information

The main sources of information for parents were the doctor $(80.49 \%)$, the pharmacist $(63.65 \%)$ and the drug leaflet $(53.36 \%)$. In $12.76 \%$ of cases, the parents stated that in the practice of self-medication for their children they also took into account the advice/information received from the close entourage (relatives, friends, colleagues). In relation to this question, the following answers were also found: the internet (especially "mother sites") - 6.56\%, press articles, medical brochures (3.36\%). Figure 1 graphically informs the sources of information of the investigated parents about the drugs given to their children.

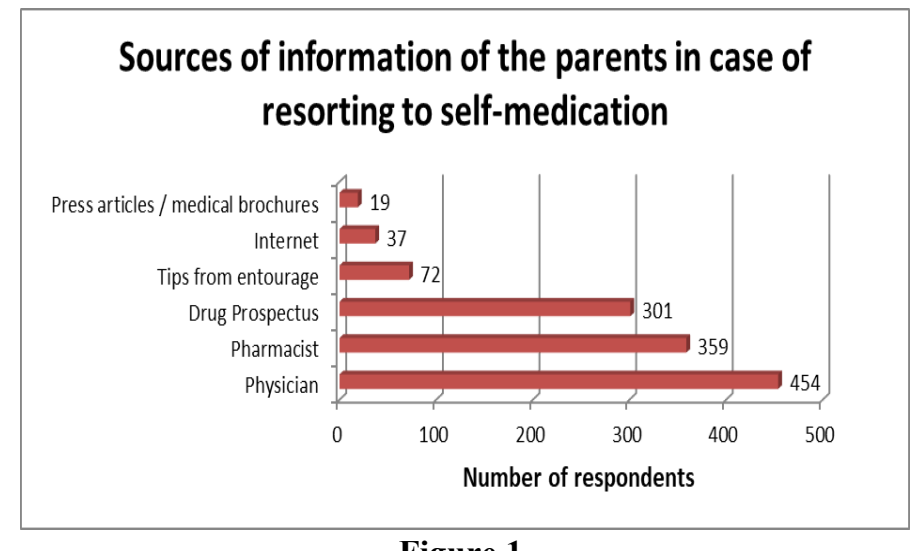

Figure 1.

Parents' sources of information regarding the self-medication treatment of their children

The persons responsible for the child's self-medication For the following question "Who in your family administer most often self-medication to the child?" we found that mothers accounted for $71.27 \%$ of those who use this practice when their child presents various pathological symptoms. The fathers used selfmedication only in $6.91 \%$ of cases. Respondents said that in $14.36 \%$ of cases, both parents are responsible for the self-medication administration, without prior medical attention when their child have symptoms/ affections they consider to be benign. Other caregivers (grandparents, other relatives) used auto-medication for the paediatric patient only in $7.44 \%$ of cases.
Reasons why parents use self-medication

The main reason why parents resort to self-medication of their child is their previous experience of the "per se" symptom of the child (72.8\%). The lack of time for medical consultation from the first signs of the disease accounts for $29.3 \%$ of parents' responses. Other factors cited: the close entourage's advice, 9.12\% and the internet (especially mothers' websites, 6.41\%) occupy a small share (Figure 2). The present study highlighted the fact that there is a significant link between the parent's confidence to feel well-informed in order to properly treat the child's symptoms without any risk and to resort to self-medication.

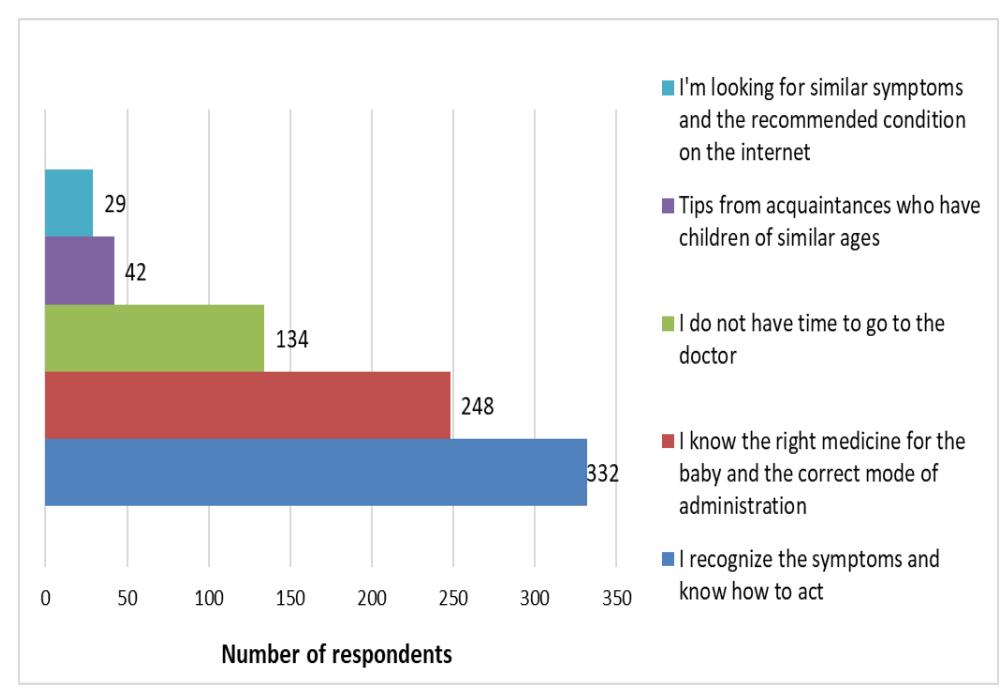

Figure 2.

Parents' main reasons for self-medicating the child 
FARMACIA, 2018, Vol. 66, 5

Symptoms for which parents prefer the self-medication of the child

In response to this question, parents say they resort to this kind of treatment when their child had the following symptoms: fever (58.87\%), pain of various causes ("neck", "teeth", abdominal) 36.81\%, cough (34.47\%), cold (34.21\%), diarrhoea (27.71\%), the lack of appetite or lack of energy (21.44\%) or the desire to "strengthen" the immunity of the body $(19.82 \%)$. Fever was the main reason evoked by parents who prefer the self-medication of the child, possibly due to the stress and excessive anxiety that this symptom generates and its potential complications (e.g. febrile seizures).
Pain, in various forms, cough, especially the nocturnal exhaustion of the child, nasal obstruction that affects children's sleep and comfort are sources of concern for respondents' parents and factors that have led to self-medication.

Improving the appetite and the deficient immune system by administering vitamins and nutritional supplements, without the doctor's opinion, are symptoms cited by parents at an insignificant proportion.

Figure 3 presents the main symptoms for which the studied population has resorted to children's selfmedication.

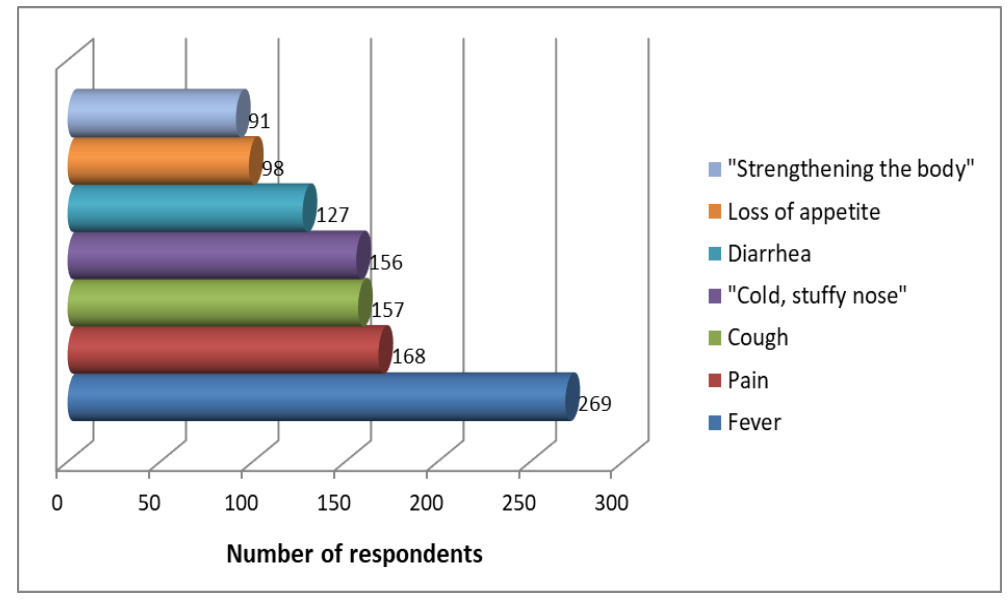

Figure 3.

Symptoms/pathologies for which parents prefer the self-medication of the child

Drugs administered to the child as self-medication The most commonly drugs used as self-medication when their child presents various pathological symptoms belong to the following pharmacological classes: analgesic-antipyretic drugs $92.74 \%$, antitussive and mucolytic drugs $53.84 \%$, vitamins and dietary supplements $49.14 \%$, nasal decongestants in the form of solutions and nasal spray $40.14 \%$.

Figure 4 presents the drugs with an increased incidence of self-medication as the responding parents mentioned.
While mentioning the possibility of bacterial resistance among the risks of self-medication, $34.61 \%$ of the interviewed parents cite antibiotics among drugs already used as self-medication when their child experiences a "cold" or fever $>39^{\circ} \mathrm{C}$. Of these, penicillins (amoxicillin, amoxicillin + clavulanic acid) accounted for $58.18 \%$ of all administrations and macrolides (erythromycin, clarithromycin, azithromycin) for $37.4 \%$. Homeopathic remedies were quoted by $31.8 \%$ of parents.

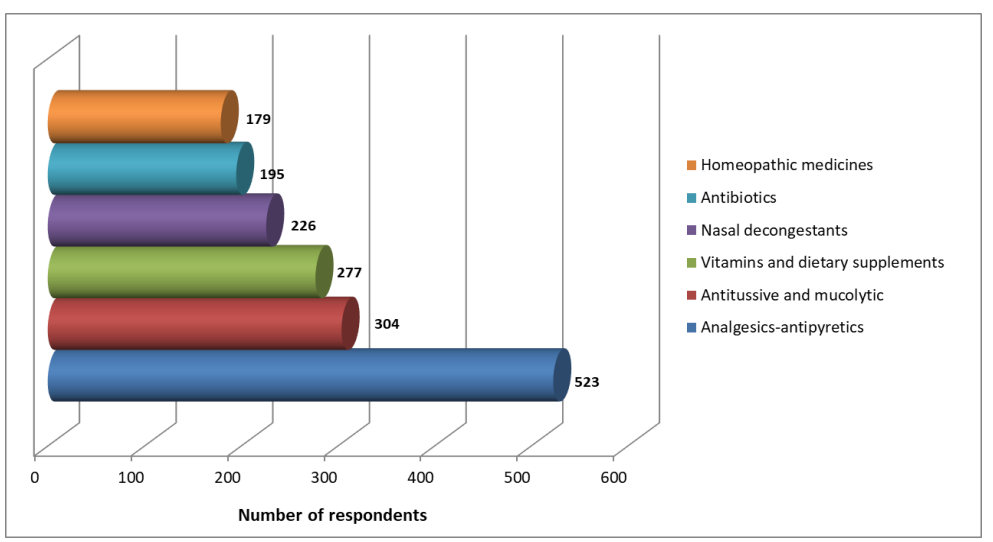

Figure 4.

Groups of drugs most commonly administered without a medical prescription 
Analysing the questionnaires, we found that in $34.38 \%$ of cases the responding parents stated that they administered the child drugs outside the current regulations, according to the patient's group of age: terpenes as inhalations or lotions (in $7.18 \%$ of cases), loperamide in children under 6 years old $(12.46 \%)$, metoclopramide (14.21\%) under the age of 3. Ibuprofen (Nurofen $^{\circledR}$, Paduden ${ }^{\circledR}$ ) $(52.19 \%)$ and paracetamol $\left(\right.$ Panadol $\left.^{\circledR}\right)(40.55 \%)$ were the most commonly used drugs for self-medication for their child, for analgesic and antipyretic purposes $(92.74 \%$ cases).

Using this questionnaire, we also wanted to evaluate parents' knowledge regarding the efficacy and inconvenience of paracetamol versus ibuprofen therapy. Table II shows the detailed answers of the respondents parents about the efficacy of the two drugs, both having analgesic - antipyretic effect.

Table II

The parents' answers concerning the efficacy of the pharmacotherapy of ibuprofen versus paracetamol

\begin{tabular}{|c|c|c|c|c|}
\hline \multicolumn{2}{|c|}{ Parents } & \multicolumn{3}{c|}{ Therapeutic efficacy } \\
\hline Number & Percentage & $\mathbf{I}>\mathbf{P}$ & $\mathbf{I}=\mathbf{P}$ & $\mathbf{I}<\mathbf{P}$ \\
\hline 272 & $51.08 \%$ & +++ & - & - \\
\hline 236 & $44.95 \%$ & - & +++ & - \\
\hline 17 & $3.23 \%$ & - & - & +++ \\
\hline
\end{tabular}

$\mathrm{I}=$ ibuprofen; $\mathrm{P}=$ paracetamol

We have found that over $50 \%$ of the investigated parents consider ibuprofen as a more effective drug than paracetamol, especially for dental pain.

We also sought to investigate whether parents are aware of the potential side effects that might occur during treatment with ibuprofen or paracetamol.

For ibuprofen: only $12.58 \%$ of parents cited correctly all the side effects of this drug (included in the questionnaire), $51.95 \%$ of parents partially recognized the side effects of the nonsteroidal anti-inflammatory drug, in $24.64 \%$ of cases they stated that ibuprofen is a hepatotoxic drug.

For paracetamol: $58.68 \%$ of respondents have shown a good understanding of the potential risks induced by this compound, $20.03 \%$ of parents had only a partial knowledge of the potential side effects of this analgesic-antipyretic drug, but they know that paracetamol given in inappropriate doses has a hepatotoxic effect. Nine percent $(9 \%)$ of the questioned parents believe that paracetamol is a "risk-free" drug, and which they believe to be non-toxic.

Analysing of the composition of some pharmaceutical specialties

In this research we also intended to investigate parents' knowledge regarding the recognition of the 2 active principles (paracetamol and ibuprofen) included in the most commonly used pharmaceutical specialties as self-medication, to combat fever or cold (Figure 5).

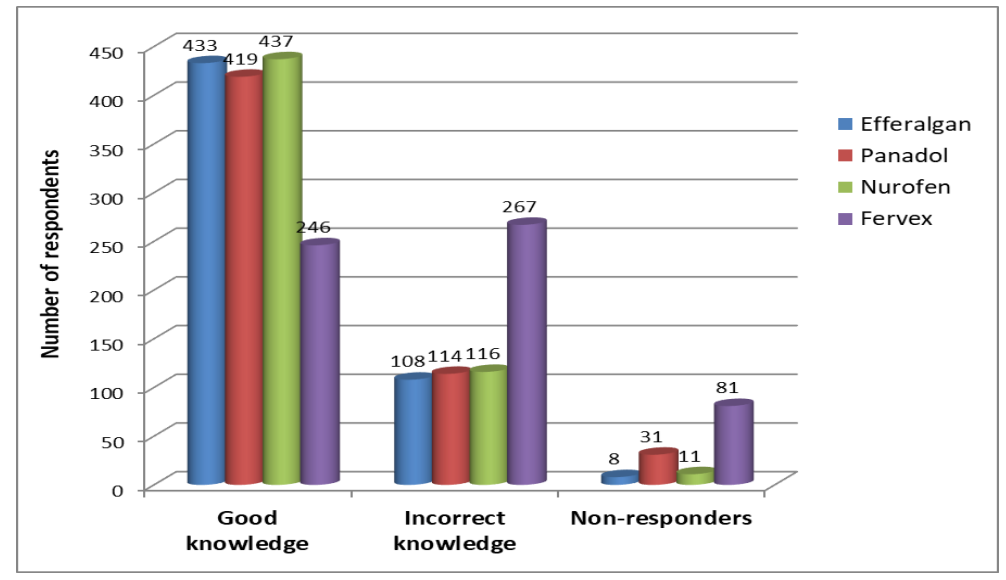

Figure 5.

Parents' knowledge over the composition of 4 pharmaceutical specialties administered to the child for analgesicantipyretic purposes

The composition of Nurofen ${ }^{\circledR}$ and Efferalgan ${ }^{\circledR}$ is best known by parents $(77.48 \%$ and $76.77 \%$ respectively). By not recognizing the active principle of a pharmaceutical formulation administered to a child as self-medication, parents contribute to the increasing of the iatrogenic risk in paediatrics.

\section{The origin of drugs}

Regarding the origin of drugs used as self-medication, $93.61 \%$ of parents (528 persons) stated that these drugs are found in the family pharmacy kit; in $4.78 \%$ ( 27 people) of cases it was reported that they were bought from the pharmacy on another occasion or 
given by a close acquaintances, in $1.59 \%$ cases ( 9 persons).

The convenient access to a "family pharmacy kit", largely made up of previously prescribed drugs (which may have exceeded the expiration date) significantly increases the appeal to parents' self-medication and also the associated risks of this practice.

Risks of self-medication practiced by parents in children under 12 years old

Although aware of the negative implications of selfmedication in a child under the age of 12 , when asked to mention some of the ad hoc risks of this practice, we found that, in a significant proportion, parents did not have clear views about this concept. In response to this question the responding parents mentioned: the risk of allergic reactions $58.68 \%$ (331 persons), the risk of overdose $48.22 \%$, the worsening of the initial symptoms $46.63 \%$ (263 persons), the risk of hepatotoxicity $45.92 \%$ (259 persons), the masking of the evolution of a severe disease $42.19 \%$ (238 persons), the appearance of the bacterial resistance $16.64 \%$ (94 persons) (Figure 6).

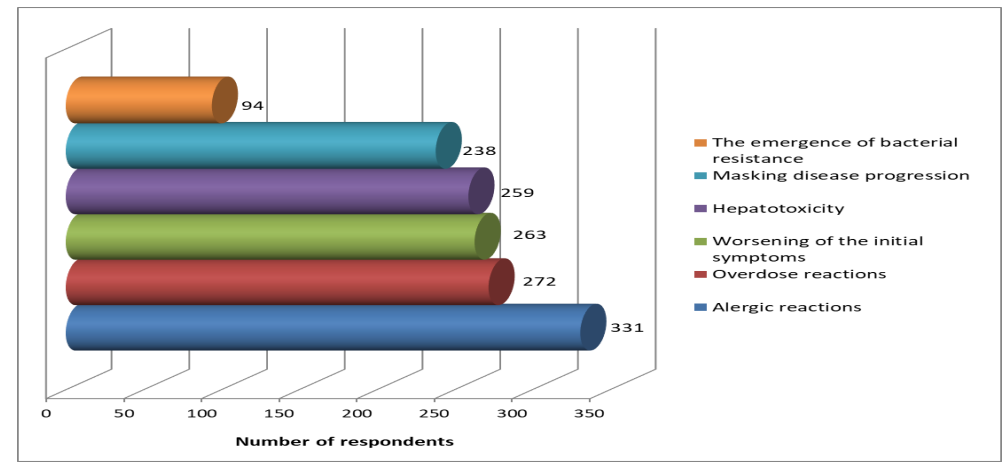

Figure 6.

Respondents' opinions on self-medication risks in children

\section{Statistical analysis}

After eliminating the insignificant variables $(p>0.05)$ we obtained the following generalized linear model:

Call: $\operatorname{glm}$ (formula $=$ automed $\sim$ bage $1+$ bage $2+$

bage $3+$ bage $4+$ mother + others + sympt $1+$

sympt $3+\operatorname{sympt} 4+$ medf 1, family $=\operatorname{binomial}()$,

$$
\text { data }=\text { chest }) \text {, }
$$

$$
\text { AIC: 322.1, }
$$

where: bage is the age of the child, sympt - the symptoms and the medf - the drug form.

As it can be seen from the data analysis, the "child age" variable is the most significant. Its weight is maximal before 6 months $\left(\mathrm{p}=3.42 * 10^{-6}\right)$, decreasing as the child's age increases.
For the persons responsible for the self-medication administration, the mother ranks first with a value of $p=7.24 * 10^{-6}$ (highly significant), followed by "others" with a value $\mathrm{p}=0.0054$, much smaller but still significant.

The symptoms for self-medication use were also statistically relevant. The most important was fever, with $\mathrm{p}=0.00842$, followed by cough and diarrhoea. A lesser, but yet profound importance is the pharmaceutical form of the drug. The drinkable forms with $\mathrm{p}=0.02482$ were preferred.

The AIC value has decreased from 359.23 to 322.1 , so the last model is preferred to the first one.

The final model is graphically represented in the figure below (Figure 7).

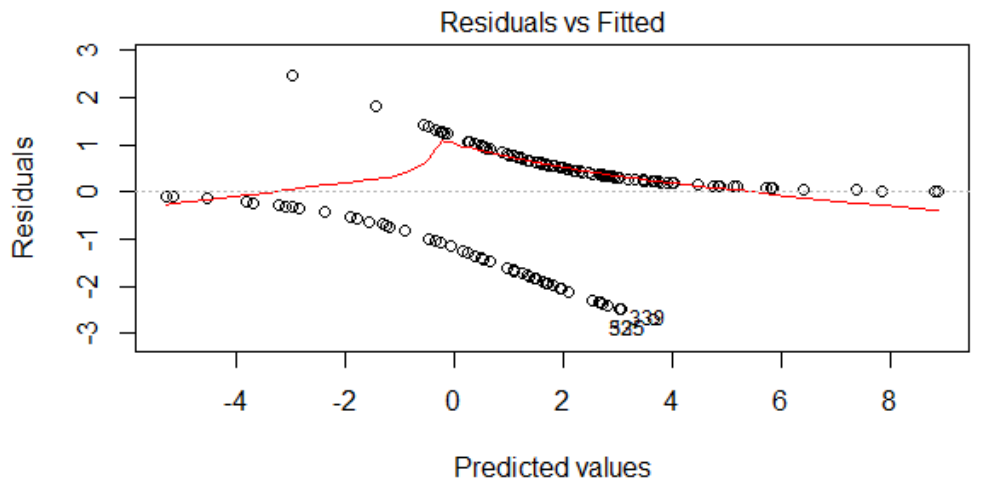

Figure 7.

Graphical representation of the chosen model 
In our study, a total of 600 questionnaires were distributed to parents, of which 564 were returned and analysed $(96.90 \%)$, which allows a meaningful interpretation of the obtained results.

The prevalence of self-medication administered to children by parents as a result of this research was of $81.02 \%$, confirming that this practice is an important and common issue that must be related with the recently established (2012) regulations on the management of OTC in the paediatric population.

According to other recent studies conducted in the USA and United Kingdom, paediatric self-medication percentage ranges between $66-83 \%[2,7]$.

In our study, we noticed that the largest proportion of parents who used self-medication in children was between 30 - 39 years of age (78.41\%) and attended university studies $(67.33 \%)$. Regarding the origin of drugs used as self-medication for children, several studies have shown that they come from the home pharmacy kit (in $42-70 \%$ of cases) [3, 19].Our study confirms these results, as the major source of drugs used by parents to self-medicate children $(83.61 \%)$. The parents' easy access to the home medicines is a major factor in increasing the prevalence of selfmedication in children, being responsible of increasing also its negative consequences.

According to the present study, the most invoked reason for respondents to self-medication was the safety of the children and that they "know best what is the right medicine" in a clinical setting apparently similar to the other medical situation in which the child received medical advice $(62.89 \%)$.

Other factors like the lack of time $-29.3 \%$ or advice received from close acquaintances $-9.12 \%$ occupy a much smaller role within the reasons mentioned by the respondent parents. The data show that parents often overestimate their medical and pharmacotherapeutic knowledge. Another two recent studies that were published in 2012 and 2016 showed that $27 \%$ and $41 \%$ of parents consider themselves well informed about the symptoms and how to administer medicines to their child $[5,6,17]$. Corroborating the data on this indicator, we can say that the panic induced by the child's symptom combined with a wide ignorance of the medication used and the convenient access to the family pharmacy are among the main reasons that explain the frequent call of parents to self-medication.

Mothers were involved in $71.27 \%$ of the cases of parents who have resorted to this treatment for their child. It seems that the emotional impulsivity of the mother caused by an excessive anxiety about the "per se" symptom and the discomfort of the child explains its major role in increasing the prevalence of paediatric self-medication.

In our study, the doctor is the first reference that guides the behaviour of parents who self-medicate their child $(80.49 \%)$. This aspect has a much higher weight to our research than it has in other studies of similar themes $[11,15]$. The $63.65 \%$ pharmacist counselling and the drug leaflet (53.56\%) were also important sources of information for parents.

The most common symptoms treated by the parents without prior medical attention were fever $(58.87 \%$ cases), pain (36.80\%), cough (34.47\%) and stuffy $(34.21 \%)$. These results are consistent with the conditions commonly found in children during the study period. Numerous multicentre studies show increased use of self-medication in the presence of child's fever, fact that was explained by the stress state generated by the symptom $[5,7,13]$.

Cough, sore throat and stuffy, evocative symptoms of acute rhino pharyngitis were quoted in large proportions by the respondents, although the FDA published in 2011 a series of recommendations and restrictions on the medication used to treat these symptoms that occur in children under 6 years old [9]. Ibuprofen $\left(\right.$ Nurofen $^{\circledR}$, Algin $^{\circledR}$ ) and paracetamol (Fervex ${ }^{\circledR}$, Efferalgan $^{\circledR}$ and Panadol ${ }^{\circledR}$ ) are the most common drugs cited by the parents included in the study $(92.74 \%)$. Other numerous studies confirm that analgesic antipyretic drugs are the most frequently used treatments for children $[5,12,16,20]$.

Although nowadays, due to the gastric, renal toxicity and unpredictable allergic reactions common to NSAIDs (nonsteroidal anti-inflammatory drug), the international paediatric publications do not recommend ibuprofen as first-line treatment in children under 6 years old $[2,5,12]$. Our study shows that this substance was the most frequently used medication $(51.08 \%)$ versus (44.95\%) paracetamol. Moreover, $51.95 \%$ of parents interviewed made confusion between the name of the active principle (e.g. paracetamol) and the trade name (e.g. Efferalgan ${ }^{\mathbb{B}}$ ), erroneously quoting ibuprofen as the active substance in this product.

The self-medication practice with drugs for the treatment of cough was highlighted in $53.84 \%$ of cases, without being able to make a clear distinction between antitussives or mucolytic drugs administered by the parents. From our study, we found that with the development of the natural medicine, the use of phytotherapy or homeopathic remedies has also expanded to the paediatric population $(31.80 \%)$. Almost $40 \%$ of parents used nasal sprays with local decongestant effect of which $3.21 \%$ have a compound that contraindicated for the child's age.

Although $34 \%$ of parents mentioned "the risk of resistance of the bacteria", it has been reported that the parents have given antibiotics in the form of self-medication, most commonly from the penicillin group and the new generation of macrolides.

\section{Conclusions}

From this study, the following conclusions can be drawn: the prevalence of family self-medication in 
FARMACIA, 2018, Vol. 66, 5

children under 12 years old was $81.02 \%$; mothers between the ages of 30 and 39 years old, with university studies, have used self-medication for their children in $71.27 \%$ of the cases, mostly using the family pharmacy kit $(83.61 \%)$; the doctor $(80.49 \%)$, the pharmacist $(63.65 \%)$ and the drug leaflet $(53.56 \%)$ are the main landmarks that guide the behaviour of parents when they resort to self-medication for their child; fever, pain and cough were the symptoms most commonly used by parents to self-medicate, and ibuprofen $(51.08 \%)$ and paracetamol (44.95\%) were the most commonly administered drugs by the respondent parents; $51.08 \%$ of parents consider ibuprofen to be more effective than paracetamol and they know only some (and not all) of the side effects of this NSAID; fear of post-medical allergic reactions (58.68\%), over dosage $(48.22 \%)$ and worsening of the disease $(46.63 \%)$ are the most frequently reported risks of self-medication in children, by parents; the increased prevalence of self-medication in children requires the implementation of educational programs (information and therapeutic programs) for parents regarding the risks of this practice. New studies will between needed in order to assess the impact of these therapeutic education campaigns.

\section{References}

1. Bertoli AD, Silveira MPT, Menezes AMB, Assuncao ACF, Goncalves H, Hallal PC, Tracking of Medicine Use and Self-Medication From Infancy to Adolescence: 1993 Pelotas (Brazil) Birth Cohort Study. J of Adoles Health, 2012; 51(6): S11-S15.

2. Bouville B, Bismuth M, Escourrou B, Durrieu G, Self-medication in children by parents : a real risk? Transversal descriptive study. La revue du praticien, 2010; 60(6): 27-34.

3. Du Y, Knopf H, Self-medication among children and adolescents in Germany: Results of the National Health Survey for Children and Adolescents (KiGGS). Br H Clin Pharmacol., 2009; 68: 599-608.

4. Hameen-Arttila K, Lindell-Osuagwu L, Sepponen K, Vainio K, Halonen P, Ahonen R, Factors associated with medicine use among children aged under 12 years-a population survey in Finland. Pharmacoepidemio Drug Saf., 2010; 19(4): 400-407.

5. Heard K, Bui A, Mlynarchek SL, Green JL, Bond GR, Clark RF, Kozer E, Koff RS, Dart RC, Toxicity from repeated doses of acetaminophen in children: assessment of causality and dose in reported cases. Am J Ther., 2014; 21(3): 174-183.

6. Jemaa FC, Khaldi A, Bessioud L, Borhene J, akkad T, Ltaief G, Self medication in children at the District of
Tunis (Tunisia): Focus on antibiotic self medication. Pediatric Research, 2010; 68: 645.

7. Jensen JF, Gottschau M, Siersma VD, Graungaard AH, Holstein BE, Knudsen LE, Association of maternal self-medication and over-the-counter analgesics for children. Pediatrics, 2014; 133(2): e291-e298.

8. Knopf H, Wolf IK,Sarganas G, Zhuang W, Rascher W, Neubert A, Off-label medicine use in children and adolescents: results of a population-based study in Germany. BMC Public Health, 2013; 13: 1-12.

9. Legros G, Les determinants de l'application, par les medecins generalistes, des recentes recommandations de l`AFSSAPS sur la prise en charge de la toux aigue chez le nourrisson (etude qualitative a partir de 17 entretiens semi-directifs), 2013.

10. Maiman LA, Becker MH, Katlic AW, Correlates of mother's use of medications for their children. Soc Sci Med., 1986; 22(1): 41-51.

11. Mohanna M, Self-medication with antibiotic in children in Sana's City, Yemen, Oman Medical J, 2010; 25(1): 41-41.

12. Nydert P, Kimland E, Kull I, Lindermalm S, Overthe-counter drug use - estimations within the Swedish paediatric population. Eur J Pediatr., 2011; 170(5): 583-588.

13. Jakubowski P, Łukasz P, Waldemar G, Recreational use of popular OTC drugs - pharmacological review. Farmacia, 2018; 66(2): 209-215.

14. Schillie SF, Shehab N, Thomas KE, Budnitz DS, Medication overdoses leading to emergency department visits among children. Am J Prev Med., 2009; 37(3): 181-187.

15. Siponen S, Ahonen R, Kiviniemi V, Hameen-Anttila $\mathrm{K}$, Association between parenteral attitudes and selfmedication of their children. Int J Clin Pharm., 2013; 35(1): 113-120.

16. Sontakke S, Magdum A, Jaiswal K, Bajait C, Dakhale G, Evaluation of parenteral perception about selfmedication and other medicine use practices in children. Eur J Pharmac Med Res., 2015; 2(7): 179-185.

17. Tournadre R, Moyens d'informations et attitudes des parents face a des problemes de sante courants concernant leurs enfants. Clermont FD-BCIU-Sante, 2012; 2012(1): 91-100.

18. Vernacchio L, Kelly JP, kaufman DW, Mitchell AA, Medication use among children $<12$ years of age in the Unites States: results from the Slone Survey. Pediatrics, 2009; 124(2): 446-454.

19. Wonk ICK, Chua SS, Edmondson H, Children's over the counter medicines pharmacoepidemiological (COPE) study. Int J Pharm Pract., 2007;15(1): 17-22.

20. Ylinen S, Anttila KH, Sepponen K, Lindblad AK, Ahonen $\mathrm{R}$, The use of presciption medicines and self-medication among children - a population-based study in Finland. Pharmacoepidemiology Drug Safety, 2010; 19: 1000-1008. 